\title{
Analysis of the Determinants of Third Party Funds PT. Bank Muamalat Indonesia Tbk
}

\author{
Devi Yana ${ }^{1}$, Windari ${ }^{2}$, Ali Hardana ${ }^{3}$, Abdul Nasser Hasibuan ${ }^{4}$ \\ ${ }^{1}$ IAIN Padangsidimpuan (Perbankan Syariah, FEBI, IAIN Padangsidimpuan) \\ ${ }^{2}$ IAIN Padangsidimpuan (Hukum Syariah, FEBI, IAIN Padangsidimpuan) \\ ${ }^{3}$ IAIN Padangsidimpuan (Perbankan Syariah, FEBI, IAIN Padangsidimpuan) \\ ${ }^{4}$ IAIN Padangsidimpuan (Perbankan Syariah, FEBI, IAIN Padangsidimpuan) \\ deviyana@gmail.com ${ }^{1}$, wwindariok@gmail.com ${ }^{2}$ alihardana@iain-padangsidimpuan.ac.id $^{3}$ \\ hasibuanabdulnasser@iain-padangsidimpuan.ac.id ${ }^{4}$
}

\begin{abstract}
ABSTRAK
Dana Pihak Ketiga (DPK) terdiri dari giro, tabungan, deposito. Kenaikan DPK pada PT. bank Muamalat Indonesia Tbk, terus mengalami peningkatan dari tahun 2010-2014 namun mengalami penurunan dari tahun 2015-2016 dan meningkat kembali pada tahun 2017 kemudian menurun kembali di tahun 2018. Peningkatan dan penurunan jumlah DPK PT. Bank Mualamat Indonesia tentu saja dipengaruhi oleh beberapa factor diantaranya iflasi, BI Rate, nilai tukar, dan jumlah uang beredar. Penelitian ini merupakan penlitian kuantitatif. data yang digunakan adalah data time series triwulan tahun 2010-2018 yang di publikasikan oleh Bank Indonesia dan PT. Bank Muamalat Indonesia Tbk. melalui situs resmi www. bi.go id dan www.bankmuamalat.co.iddianalisis dengan menggunakan eviews9. Hasil penelitian ini menunjukan bahwa secara parsial Inflasi berpengaruh terhadap DPK. BI Rate berpengaruh secara parsial terhadap DPK. Nilai Tukar Rupiah secara parsial berpengaruh negatif terhadap DPK. Jumlah Uang Bereda berpengaruh secara parsial terhadap DPK. Dan Inflasi, BI Rate, Nilai Tukar Rupiah dan Jumlah Uang Beredar berpengaruh secara simultan terhadap DPK.
\end{abstract}

Kata Kunci: Dana Pihak Ketiga, Inflasi, BI Rate, Nilai Tukar Rupiah, Jumlah Uang Beredar

\section{ABSTRACT}

Third Party Funds (DPK) consist of demand deposits, savings, time deposits. The increase in DPK at PT. bank Muamalat Indonesia Tbk, continued to increase from 2010-2014 but decreased from 2015-2016 and increased again in 2017 then decreased again in 2018. The increase and decrease in the amount of DPK PT. Bank Mualamat Indonesia is of course influenced by several factors including inflation, BI Rate, exchange rate, and the money supply. This research is a quantitative research. the data used is time series data for the quarter 2010-2018 published by Bank Indonesia and PT. Bank Muamalat Indonesia Tbk. through the official website www. bi.go id and www.bankmuamalat.co.id were analyzed using eviews9. The results of this study indicate that inflation partially affects TPF. The BI Rate has a partial effect on DPK. The Rupiah Exchange Rate partially has a negative effect on DPK. The amount of the Money Supply has a partial effect on DPK. And Inflation, BI Rate, Rupiah Exchange Rate and Money Supply have a simultaneous effect on DPK.

Keywords: Third Party Funds, Inflation, BI Rate, Rupiah Exchange Rate, Total Money Supply 


\section{A. PENDAHULUAN}

Dana Pihak Ketiga merupakan dana yang dihimpun oleh bank yang berasal dari masyarakat baik individu maupun badan usaha, Muhammad (2005:411), Dana Pihak Ketiga (DPK) terdiri dari giro, tabungan, deposito. Kenaikan DPK pada PT. Bank Muamalat Indonesia Tbk, terus mengalami peningkatan dari tahun 2010-2014 namun mengalami penurunan dari tahun 2015-2016 dan meningkat kembali pada tahun 2017 kemudian menurun kembali di tahun 2018.

Peningkatan dan penurunan jumlah DPK PT. Bank Mualamat Indonesia tentu saja dipengaruhi oleh beberapa faktor diantaranya inflasi, BI Rate, nilai tukar, dan jumlah uang beredar.Penelitian ini dilakukan untuk melihat apakah ada pengauh untuk inflasi, BI Rate, nilai tukar dan jumlah uang beredar terhadap Dana Pihak Ketiga PT. Bank Mualamat Indonesia Tbk.

Tabel 1.1

Data DPK, Inflasi, Bi Rate, Nilai Tukar Rupiah

Dan Jumlah Uang Beredar.

\begin{tabular}{|l|l|l|l|l|l|}
\hline Tahun & $\begin{array}{l}\text { DPK } \\
\text { (Dalam } \\
\text { Miliar } \\
\text { Rupiah) }\end{array}$ & $\begin{array}{c}\text { Infla } \\
\text { si } \\
(\%)\end{array}$ & $\begin{array}{c}\text { BI } \\
\text { Rate } \\
(\%)\end{array}$ & $\begin{array}{c}\text { Nilai } \\
\text { Tukar }\end{array}$ & $\begin{array}{l}\text { JUB } \\
\text { (Triliun } \\
\text { Rupiah) }\end{array}$ \\
\hline 2010 & $\begin{array}{l}\text { Rp. } \\
17.393\end{array}$ & 6,96 & 6,50 & Rp. 8.991 & $\begin{array}{l}\text { Rp.2.471. } \\
205\end{array}$ \\
\hline 2011 & $\begin{array}{l}\text { Rp. } \\
26.658\end{array}$ & 3,79 & 6,75 & Rp. 9.068 & $\begin{array}{l}\text { Rp.2.877. } \\
219\end{array}$ \\
\hline 2012 & $\begin{array}{l}\text { Rp. } \\
34.903\end{array}$ & 4,30 & 5,75 & Rp. 9.670 & $\begin{array}{l}\text { Rp.3.307. } \\
507\end{array}$ \\
\hline 2013 & $\begin{array}{l}\text { Rp. } \\
41.790\end{array}$ & 8,38 & 7,50 & $\begin{array}{l}\text { Rp. } \\
12.189\end{array}$ & $\begin{array}{l}\text { Rp. } \\
3.730 .197\end{array}$ \\
\hline
\end{tabular}

\begin{tabular}{|l|l|l|l|l|l|}
\hline 2014 & $\begin{array}{l}\text { Rp. } \\
51.201\end{array}$ & 8,36 & 7,75 & $\begin{array}{l}\text { Rp. } \\
12.440\end{array}$ & $\begin{array}{l}\text { Rp. } \\
4.173 .326\end{array}$ \\
\hline 2015 & $\begin{array}{l}\text { RP. } \\
45.078\end{array}$ & 3,35 & 7,50 & $\begin{array}{l}\text { Rp. } \\
13.795\end{array}$ & $\begin{array}{l}\text { Rp. } \\
4.546 .743\end{array}$ \\
\hline 2016 & $\begin{array}{l}\text { Rp. 41. } \\
920\end{array}$ & 3,02 & 4,75 & Rp.13.436 & $\begin{array}{l}\text { Rp. } \\
5.004 .976\end{array}$ \\
\hline 2017 & $\begin{array}{l}\text { Rp. } \\
48.687\end{array}$ & 3,61 & 4,25 & $\begin{array}{l}\text { Rp. } \\
13.548\end{array}$ & $\begin{array}{l}\text { Rp. } \\
5.419 .165\end{array}$ \\
\hline 2018 & $\begin{array}{l}\text { Rp. } \\
45.636\end{array}$ & 3,13 & 6,00 & $\begin{array}{l}\text { Rp. } \\
14.481\end{array}$ & $\begin{array}{l}\text { Rp. } \\
5.760 .046\end{array}$ \\
\hline
\end{tabular}

Berdasarkan data diatas maka peneliti tertarik mengambil judul "Analisis Determinan Dna Pihak Ketiga PT. Bank Muamalat Indonesia Tbk".

\section{B. METODE}

Pengambilan data yang dihimpun langsung oleh peneliti disebut data sekunder yang di dapatkan dari laporan Tahunan Dana Pihak Ketiga, Inflasi, Bank Indonesia Rate, Nilai Tukar Rupiah, dan Jumlah Uang Beredar. Yang kemudian diolah dengan menggunakan Eviews9. Adapun analisis data dalam penelitian ini adalah sebagai berikut:

1. Statistik Deskriptif

2. Uji Normalitas

3. Uji Linearitas

4. Uji Asumsi Klasik
a) Uji Multikolinearitas
b) Uji Autokorelasi
c) Uji Heteroskedastisitas

5. Uji Regresi Berganda 
$\mathrm{Y}(\mathrm{DPK})=a b 1 \mathrm{X} 1$ (Inflasi) $+\mathrm{b} 2 \mathrm{X} 2(\mathrm{BI}$ rate $)+$ b3X3 (Nilai Tukar Rupiah + b4X4 (Jumlah Uang Beredar) +e

Keterangan:

Y $\quad$ : variabel terikat (Dana Pihak Ketiga)

a : kostanta

b1, b2 : koefisien regresi

X1 : variabel bebas (Inflasi)

X2 : variabel bebas (Bank Indonesia Rate)

X3 : variabel bebas (Nilai Tukar Rupiah)

X4 : variabel bebas (Jumlah Uang Berdar)

e : error

6. Uji Hipotesis
a. Koefisien Determinasi (R2)
b. Uji Parsial (t)
c. Uji Simultan (F)

\section{HASIL DAN PEMBAHASAN}

1. Statistik Deskriptif

Tabel 3

Hasil Statistik Deskriptif

\begin{tabular}{|c|c|c|c|c|c|}
\hline & DPK & INFLASI & BI RATE & $\begin{array}{c}\text { NILAI } \\
\text { TUKAR }\end{array}$ & JUB \\
\hline Mean & $\begin{array}{c}371560 \\
49\end{array}$ & 5.055714 & 6.221429 & $\begin{array}{c}115757 \\
1\end{array}$ & $\begin{array}{c}72211 \\
0\end{array}$ \\
\hline $\begin{array}{c}\text { Maxsimu } \\
\mathrm{m}\end{array}$ & $\begin{array}{c}534969 \\
85\end{array}$ & 8.400000 & 7.750000 & $\begin{array}{c}149290 \\
0\end{array}$ & $\begin{array}{c}14571 \\
88\end{array}$ \\
\hline $\begin{array}{c}\text { Minimu } \\
\mathrm{m}\end{array}$ & $\begin{array}{c}120202 \\
56\end{array}$ & 2.880000 & 4.250000 & $\begin{array}{c}859700 \\
0\end{array}$ & $\begin{array}{c}49411 \\
1\end{array}$ \\
\hline $\begin{array}{c}\text { Obsevati } \\
\text { ons }\end{array}$ & 36 & 36 & 36 & 36 & 36 \\
\hline
\end{tabular}

Sumber: output eviews9, data diolah

2. Uji Normalitas
POINT Vol. 1, No. 2, Des 2020

Berdasarkan hasil output tersebut dilihat bahwa nilai Prop. JB Hitung sebesar $0,239295>0,05$ sehingga dapat disimpulkan bahwa residul berdistribusi normal yang artinya asumsi klasik tentang kenormalan telah terpenuhi.

3. Uji Linearitas

Nilai Prob. F hitung dapat dilihat pada baris F-statistik kolom probability. Adapun hasil output diatas dapat dilihat bahwa Nilai Prob. F hitung sebesar 0,0680 lebih besar dari 0,05 (Prob. F hitung $>0,05$ ), sehingga dapat disimpulkan bahwa regresi telah memenuhi asumsi linearitas.

4. Uji Asumsi Klasik

\section{a. Uji Multikolinearitas}

Hasil uji multikolinaritas dapat dilihat pada tabel kolom Centered VIF. Nilai Centered VIF untuk variabel inflasi 1.992349, variabel BI Rate 3.431630, variabel Nilai Tukar 6.214694, dan variabel Jub 6.214694. Nilai Centered VIF dari keempat variabel lebih kecil dari 10, maka tidak terjadi multikoliaritas. Dengan demikian model di atas telah terbebas dari adanya multikoliaritas.

b. Uji Autokorelasi

Nilai Prob. F $(2,28)$ sebesar 0,3144 dapat juga disebut sebagi nilai probabilitas F hitung. Nilai Prob F hitung 0,3144 >0,05 (5\%) sehingga, berdasarkan uji hipotesis tidak terjadi gejala autokorelasi.

c. Uji Heteroskedastisitas

Nilai Prob. F hitung sebesar 0,3344 >0,05 (5\%). Maka tidak terjadi heteroskedastisitas. 


\section{Journal of Sharia Banking}

\section{Uji Regresi Berganda}

Estimation Command:

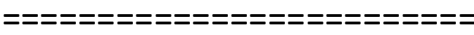

LS DPK C INFLASI BIRATE NILAITUKAR JUB

Estimation Equation:

$=====================$
DPK $=\mathrm{C}(1)+\mathrm{C}(2) *$ INFLASI +
$\mathrm{C}(3) *$ BIRATE $+\mathrm{C}(4) *$ NILAITUKAR +
$\mathrm{C}(5) *$ JUB

Forecasting Equation:

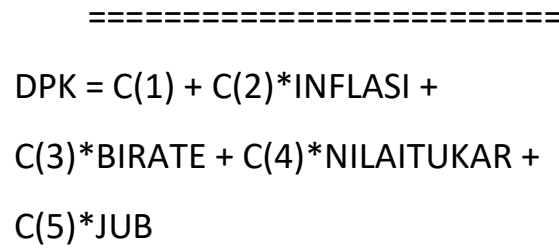

Substituted Coefficients:

$=====================$
DPK $=-2.39389619871+$
$0.0468137438007 *$ INFLASI +
$0.17288237247 *$ BIRATE -
$1.78700160373 *$ NILAITUKAR +
$2.56042382738 *$ JUB

Penelitian ini bertujuan untuk melihat apakah ada pengaruh Inflasi, BI Rate, Nilai Tukar Rupiah, dan Jumlah Uang Beredar secara parsial maupun simultan terhadap Dana Pihak Ketiga PT. Bank Muamalat Indonesia Tbk. Hasil analisis penelitian diuraikan sacara statistik dengan menggunakan program eviews9. Nilai
R-squarted sebesar 0,896980 menunjukan bahwa proporsi pengaruh variabel inflasi, BI rate, nilai tukar rupiah, dan jumlah uang beredar sebesar $89,69 \%$. Berarti Inflasi, BI Rate, Nilai Tukar Rupiah, Dan Jumlah Uang Beredar terhadap DPK memiliki proporsi $89,69 \%$ sedangkan sisanya 10,31\% (100\% - 89,69\%) dipengaruhi oleh variabel lain yang tidak ada dalam model regresi.

1. Pengaruh Inflasi Terhadap Dana Pihak Ketiga PT. Bank Muamalat Indonesia Tbk

Inflasi adalah suatu peristiwa dalam perekonomian dimana terjadi harga-harga dari barang-barang umunya naik secara terus-menerus. Laju inflasi yang tinggi dan terkendali dapat menggangu upaya perbankan dalam pengerahan dana masyarakat. Pada PT. Bank Muamalat Indonesia Tbk periode tahun 2010-2018 peningkatan Inflasi justru meningkatkan Dana Pihak Ketiga.

Pengaruh inflasi terhadap Dana Pihak Ketiga dapat dilihat dari hasil uji $\mathrm{t}$ yang dilakukan dalam penelitian ini, maka hasil yang diperoleh yaitu nilai $t_{\text {hitung }}(2,290866)>$ $t_{\text {tabel }}(2,03951)$ dan nilai signifikansi probabilitas $(0,0292<0,05)$ maka terdapat pengaruh inflasi terhadap DPK.

2. Pengaruh BI Rate Terhadap Dana Pihak Ketiga PT. Bank Muamalat Indonesia Tbk

BI Rate adalah suku bunga kebijakan yang mencerminkan sikap kebijakan moneter yang ditetapkan oleh bank 
Indonesia dan diumumkan kepada publik. Kenaikan BI Rate akan mendorong peningkatan jumlah Dana Pihak Ketiga. Pada PT Bank Muamalat Indonesia Tbk periode tahun 2010-2018 peningkatan BI Rate akan meningkatkan Dana Pihak Ketiga.

Pengaruh BI Rate terhadap Dana Pihak Ketiga dapat dilihat dari hasil uji t yaitu nilai $t_{\text {hitung }}(4,180193)>t_{\text {tabel }}(2,03951)$ dan nilai signifikansi probabilitas $(0,0002<0,05)$ maka, terdapat pengaruh BI Rate terhadap Dana Pihak Ketiga.

3. Pengaruh Nilai Tukar Rupiah Terhadap Dana Pihak Ketiga PT. Bank Muamalat Indonesia Tbk

Nilai Tukar adalah catatan (quotation) harga pasar dari mata uang asing (foreign currency) dalam harga mata uang domestik (domestic currency), atau mata uang domestik dalam mata uang asing. Jika Nilai Tukar Rupiah terhadap Dollar menurun dan Dollar terhadap Rupiah menguat maka menyebabkan berkurangnya pendapatan rill masyarakat dan mengakibatkan kemampuan masyarakat untuk menabung di bank menjadi menurun. Pada PT. Bank Muamalat Indonesia Tbk periodet ahun 2010-2018 peningkatan Nilai Tukar rupiah akan menurunkan Dana Pihak Ketiga.

Pengaruh Nilai Tukar Rupiah Terhadap dana Pihak Ketiga dapat dilihat dari nilai uji t yaitu hasil analisis uji t menunjukan bahwa variabel Nilai Tukar Rupiah memilikinilai $t_{\text {hitung }}(-4.020735)<-t_{\text {tabel }}(-2,03951)$ dan nilai
POINT Vol. 1, No. 2, Des 2020 signifikansi probabilitas $(0.0004<0,05)$ maka, Nilai Tukar Rupiah berpengaruh negatif terhadap DanaPihakKetiga.

4. Pengaruh Jumlah Uang BeredarTerhadap Dana Pihak Ketiga PT. Bank Muamalat Indonesia Tbk

Jumlah uang Beredar adalah keseluruhan jumlah aung yang dikeluarkan secara resmi oleh bank sentral berupa uang kartal, uang giral, dan valuta asing. Apabila Jumlah Uang Beredar meningkat maka Dana Pihak Ketiga juga mengalami peningkatan. Pada PT. Bank Muamalat Indonesia Tbk periode tahun 2010-2018 peningkatan Jumlah Uang Beredar juga akan meningkatkan Dana Pihak Ketiga.

Pengaruh Jumlah Uang Beredar Terhadap dana Pihak Ketiga dapat dilihat dari nilai $u j i ~ t$ yaituhasil analisis $u j i ~ t$ menunjukan bahwa variabel Jumlah Uang Beredar memiliki nilai $t_{\text {hitung }}(8,473527)>$ $t_{\text {tabel }}(2,03951)$ dan nilai signifikansi probabilitas $(0,0000<0,05)$ maka, terdapat pengaruh Jumlah Uang Beredar terhadap Dana Pihak Ketiga.

5. Pengaruh Inflasi, BI Rate, Nilai Tukar Rupiah, dan Jumlah Uang Beredar Terhadap Dana Pihak Ketiga PT. Bank Muamalat Indonesia Tbk

Bank merupakan tempat yang paling aman untuk menyimpan uang karena bank syariah adalah lembaga keuangan yang berfungsi sebagai perantara bagi pihak yang memiliki kelebihan dana dengan 
pihak yang kekurangan dana untuk kegiatan usaha dan kegiatan lainnya sesuai dengan prinsip syariah, Zainuddin Ali (2008:1 g ) kegiatan menghimpun dan menyalurkan dana.Maka bank perlu menganalisis kondisi makro ekonomi seperti Inflasi, BI Rate, Nilai Tukar Rupiah, dan Jumlah Uang Beredar sehinnga proses pennghimpunan dana dari masyarakat berjalan dengan baik.

Secara simultan maisng-masing variabel bebas berpengaruh positif terhadap dana pihak ketiga diketahui nilai $F_{\text {hitung }}$ sebesar $(65,30130)$ $>F_{\text {tabel }}(2,68)$, dan nilai signifikansi probabilitas $(0,000000<0,05)$. Sehingga dapat disimpulkan bahwa Inflasi, BI Rate, Nilai Tukar Rupiah dan Jumlah Uang Beredar berpengaruh secara bersama-sama (simultan) terhadap DPK.

\section{PENUTUP}

\section{Kesimpulan}

Berdasarkan hasil penelitian yang dilakukan, diperoleh kesimpulan tentang pengaruh variable Inflasi, BI Rate, NilaiTukar Rupiah, dan Jumlah Uang Beredar terhadap dana pihak ketiga PT. Bank Muamalat Indonesia Tbk periode tahun 2010-2018. Kesimpulan yang diperoleh adalah sebagai berikut:

1. Inflasi berpengaruh terhadap Dana Pihak Ketiga PT. Bank Muamalat Indonesia Tbk periode tahun 2010-2018.

2. BI Rate berpengaruh terhadap Dana Pihak Ketiga PT. Bank Muamalat Indonesia Tbk periode tahun 2010-2018 .
3. Nilai Tukar Rupiah berpengaruh negatif terhadap Dana Pihak Ketiga PT. Bank Muamalat Indonesia Tbk periode tahun 2010-2018.

4. Jumlah Uang Beredar berpengaruh terhadap Dana Pihak Ketiga PT. Bank Muamalat Indonesia Tbk periode tahun 2010-2018.

5. Inflasi, BI Rate, Nilai Tukar Rupiah, dan Jumlah Uang Beredar, berpengaruh secara simultan terhadap Dana Pihak Ketiga PT. Bank Muamalat Indonesia Tbk periode tahun 2010-2018.

\section{Saran}

Semoga adanya pengetahuan masyarakat terhadap minat produk perbankan syariah

\section{DAFTAR PUSTAKA}

Adiwarman Karim, Ekonomi Makro Islam, Jakarta: Rajawali Pers, 2010.

Aulia Pohan, Potret Kebijakan Moneter Indonesia, Jakarta: PT Raja Grafindo Persada, 2008.

Boediono, Seri Sinopsis Pengantar IImu Ekonomi No. 2 Ekonomi Makro, Yogyakarta: BPFE 2012.

Muhammad, Manajemen Dana Bank Syariah, Jakarta: Rajawali Pers, 2014.

Prathama Rahardja dan Mandala Manurung, Pengantar Ilmu Ekonomi, Jakarta: Lembaga Penerbit Fakultas Ekonomi Universitas Indonesia, 2008.

Zainuddin Ali, Hukum Perbankan Syariah, Jakarta: Sinar Grafika, 2008.

Sumber Internet 
DeviYana ${ }^{1}$, Windari ${ }^{2}$, Ali Hardana ${ }^{3}$, Abdul Nasser Hasibuan ${ }^{4}$

POINT Vol. 1, No. 2, Des 2020

www.bi.go.id

www.bankmuamalat.co.id

www.ojk.go.id 